\title{
Parainfluenza 3 Respiratory Infection Associated with Pericardial Effusion in a Very Low Birthweight Infant
}

\author{
Cristina Aranda Cazón, ${ }^{1}$ Luis Arruza Gómez, ${ }^{2}$ Gloria Herranz Carrillo, ${ }^{2}$ \\ Cristina González Menchén, ${ }^{1}$ Zarife Daoud Pérez, ${ }^{1}$ José Antonio Martínez-Orgado, ${ }^{2}$ and \\ José Tomás Ramos Amador \\ ${ }^{1}$ Department of Pediatrics, Hospital Clínico San Carlos, Instituto de Investigación Sanitaria del Hospital Clínico San \\ Carlos (IdISSC), Madrid, Spain \\ ${ }^{2}$ Division of Neonatology, Hospital Clínico San Carlos, Instituto de Investigación Sanitaria del Hospital Clínico San \\ Carlos (IdISSC), Madrid, Spain
}

Correspondence should be addressed to Cristina Aranda Cazón; aranda.cristina@hotmail.com

Received 19 June 2017; Revised 10 September 2017; Accepted 27 September 2017; Published 24 October 2017

Academic Editor: Alexandre R. Marra

Copyright (c) 2017 Cristina Aranda Cazón et al. This is an open access article distributed under the Creative Commons Attribution License, which permits unrestricted use, distribution, and reproduction in any medium, provided the original work is properly cited.

Parainfluenza 3 virus is a frequent cause of respiratory infections in the pediatric population although it is uncommonly diagnosed in neonates, being usually reported as neonatal intensive care unit microepidemics. We report a case of parainfluenza 3 respiratory infection associated with pericardial effusion in a very low birthweight infant.

\section{Case Report}

We present the case of a male neonate born at week 25 of gestational age and weighed 720 grams. During pregnancy follow-up, the mother received labetalol because of gestational hypertension. Ultrasound controls during pregnancy were normal, and routine serologies were negative.

At week 25 of gestation, severe preeclampsia was diagnosed. Fetal ultrasound showed intrauterine growth retardation type 1 and redistribution in Doppler flow. Caesarean delivery was indicated due to severe preeclampsia after sulfate magnesium administration for neuronal protection and complete pulmonary maturation. The newborn needed intubation in the delivery room with $100 \%$ fraction of inspired oxygen $\left(\mathrm{FiO}_{2}\right)$ and intratracheal instillation of surfactant. Then, he was extubated and connected to nasal continuous positive airway pressure (CPAPn). When $\mathrm{FiO}_{2}$ was decreased to $30 \%$, the patient was transferred to the neonatal intensive care unit (NICU).

At 29 week postconceptional age, the infant was stable with noninvasive ventilation (mean airway pressure (MAP) $6 \mathrm{cmH}_{2} \mathrm{O}, \mathrm{FiO}_{2}$ 0.40). Suddenly, clinical deterioration occurred, involving respiratory distress, increased needs of oxygen therapy, tachypnea, bradycardia, desaturations, and frequent apnea episodes, that required intubation and mechanical ventilation (MAP $12 \mathrm{cmH}_{2} \mathrm{O}, \mathrm{FIO}_{2}$ 0.50). Laboratory tests evidenced lymphocytosis and hypertransaminasemia. Blood culture, urine culture, and cerebrospinal fluid culture were negative (Table 1). Chest X-ray showed bilateral pulmonary infiltrates and significant cardiomegaly (Figure 1(a)). Echocardiography revealed diffuse pericardial effusion involving predominantly right chambers (Figure 2). Contractility and right and left cardiac outputs were preserved as shown in Table 1.

Polymerase chain reaction (PCR) in nasopharyngeal swab was requested the day after the clinical deterioration and was positive for parainfluenza 3 virus (PIV3). The multiplex PCR used was CLART-PneumoVir. It detects 17 respiratory viruses: respiratory syncytial viruses (RSV); RSV group-A; RSV group-B; PIV1; PIV2; PIV3; PIV4; coronaviruses; human metapneumovirus; adenoviruses; enteroviruses; influenza A (including H3N2 and both seasonal and pandemic $\mathrm{H} 1 \mathrm{~N} 1), \mathrm{B}$, and $\mathrm{C}$ viruses; rhinoviruses; and bocavirus. Because newborn family members and neonatal intensive care unit staff were asymptomatic before, during or after the episode, nasopharyngeal swabs could not be 
TABLE 1: Diagnostic tests performed.

\begin{tabular}{|c|c|}
\hline Test & Results \\
\hline $\begin{array}{l}\text { Blood test before the diagnosis of the pericardial } \\
\text { effusion, during sudden clinical deterioration }\end{array}$ & $\begin{array}{c}\text { Leukocytosis } 15.08 \text { cells } / \mathrm{mm}^{3}\left(5-14.5 \text { cells } / \mathrm{mm}^{3} ; 75 \%\right. \\
\text { lymphocytes, } 12 \% \text { neutrophils }) ; \text { hemoglobin } 12.5 \mathrm{~g} / \mathrm{dl} \\
(10-13 \mathrm{~g} / \mathrm{dl}) \text { and platelet count } 280 / \mathrm{mm}^{3} \\
\left(250-450 / \mathrm{mm}^{3}\right) . \text { ALT } 203 \mathrm{U} / \mathrm{L}(6-50 \mathrm{U} / \mathrm{L}), \text { AST } \\
180 \mathrm{U} / \mathrm{L}(35-140 \mathrm{U} / \mathrm{L}), \text { C-reactive protein }(\mathrm{CRP}) 3 \text {, } \\
4 \mathrm{mg} / \mathrm{dl}(<2 \mathrm{mg} / \mathrm{dl}) ; \text { procalcitonine } 0.3 \mathrm{ng} / \mathrm{ml} \\
(<0.5 \mathrm{ng} / \mathrm{ml})\end{array}$ \\
\hline Blood culture & Negative \\
\hline Urine culture & Negative \\
\hline Cerebrospinal fluid culture & Negative \\
\hline Chest X-ray & $\begin{array}{c}\text { Bilateral pulmonary infiltrates and significant } \\
\text { cardiomegaly }\end{array}$ \\
\hline Echocardiography & $\begin{array}{c}\text { Diffuse pericardial effusion affecting predominantly } \\
\text { right chambers. Ejection fraction: } 76 \% \text {; shortening } \\
\text { fraction: } 41 \% \text {; LVO: } 355 \mathrm{ml} / \mathrm{kg} / \mathrm{min} \text {; RVO: } \\
395 \mathrm{ml} / \mathrm{kg} / \mathrm{min}\end{array}$ \\
\hline PCR in nasopharyngeal swab & Positive for parainfluenza 3 virus \\
\hline $\begin{array}{l}\text { Blood tests after the resolution of the pericardial } \\
\text { effusion }\end{array}$ & $\begin{array}{l}\text { Leukocytes } 9.8 \text { cells } / \mathrm{mm}^{3}(74.4 \% \text { lymphocytes, } 15 \% \\
\text { neutrophils); hemoglobin } 13.1 \mathrm{~g} / \mathrm{dl} \text { and platelet count } \\
255 / \mathrm{mm}^{3} \text {. ALT } 89 \mathrm{U} / \mathrm{L} / \mathrm{AST} 73 \mathrm{U} / \mathrm{L}, \mathrm{C}-\text { reactive protein } \\
\text { (CRP) } 1.7 \mathrm{mg} / \mathrm{dl} \text {; procalcitonine } 0.07 \mathrm{ng} / \mathrm{ml}\end{array}$ \\
\hline
\end{tabular}

obtained from the contacts. Other infectious causes of pericardial effusion were incompatible with the clinical picture: the patient was not treated with drugs that may had caused pericardial effusion, there was no possible traumatic cause (central venous catheter perforation and penetrating trauma), and there were not clinical, analytical, or radiological signs of other causes (tuberculosis, fungal infections, collagen diseases, etc.). Blood culture for other microorganisms, including bacteria and fungi, was negative. Because of this, PIV3 may have been the trigger for the pericardial pathology.

Due to the hemodynamic stability of the patient, a conservative approach was adopted. The patient did not require anti-inflammatory or diuretic therapy to reduce pericardial effusion. Serial echocardiograms and chest $\mathrm{X}$-ray confirmed its reduction until its complete resolution within 5 days (Figure 1(b)). Figure 1 shows the cardiomegaly at the clinical deterioration, with near complete resolution. At 36 weeks postconceptional age, the patient developed severe bronchopulmonary dysplasia (BPD), requiring high-flow nasal cannulae and $40 \%$ oxygen supplementation.

\section{Discussion}

To our knowledge, there are only two cases reported of pericardial effusion associated with parainfluenza viruses in children and none of them in the neonatal period. The first one describes an 8-month-old boy diagnosed with pneumonia and severe combined immunodeficiency. Parainfluenza 3 was isolated in respiratory secretions and pericardial and cerebrospinal fluids. Postmortem evaluation confirmed the presence of the pathogen in the lung, brain, and pericardial samples [1]. The second case is a 9-year-old immunocompetent patient with pericardial effusion in whom parainfluenza 4 was isolated in nasopharyngeal aspirate. The patient was successfully treated with ibuprofen [2]. There are two other cases reported in adults. In the first one, parainfluenza 3 viral infection was considered to be the cause of a fulminant myocarditis with pericardial effusion in a 35 -year-old woman with diabetic ketoacidosis and type 1 diabetes [3]. The second one described a 62-year-old woman with pneumonia and pericardial effusion as a result of infection with parainfluenza virus type 4 and thrombotic thrombocytopenic purpura [4].

Parainfluenza virus is an RNA virus belonging to the Paramyxoviridae family, with four types described. It is a prevailing cause of viral respiratory infection in the pediatric population after respiratory syncytial virus, enteroviruses, or human metapneumovirus. Although respiratory viral infections are usual among hospitalized newborns, they are not clinically suspected because the signs and symptoms of infection are nonspecific or too subtle. For this reason, they are seldom diagnosed in the neonatal intensive care unit. There are scarce reports presenting isolated cases like this one as most of the published data refer to neonatal intensive care unit microepidemics in which parainfluenza 3 was just one of the different viruses detected [5]. Those outbreaks are thought to be related to longer stay in the neonatal intensive care unit. As the main route of transmission of this pathogen is through infected secretions, respiratory and contact isolation is essential to prevent disease outbreaks.

Premature infant population may develop parainfluenza virus infection with atypical or even clinically unapparent signs and symptoms [6] as in our patient. Clinical signs are nonspecific (mainly respiratory with increased secretions, 


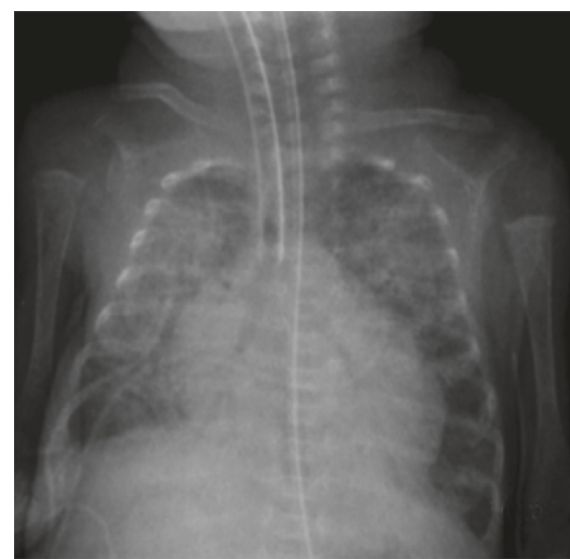

(a)

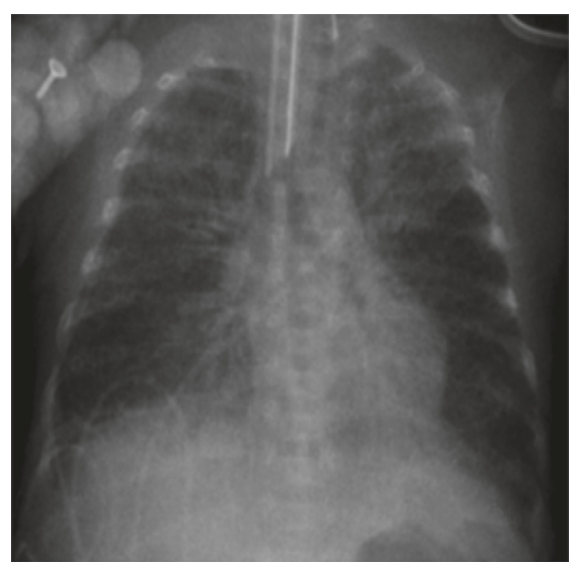

(b)

Figure 1: Acute (a) and convalescent (b) chest radiographs demonstrating cardiomegaly at the time of the clinical deterioration, with near complete resolution five days later.

respiratory distress, coughing, tachypnea, pneumonia, or apnea episodes). Diagnosis requires a high index of suspicion in the presence of suggestive symptoms, since other infecting viruses such as respiratory syncytial viruses, enteroviruses, rhinoviruses, or coronaviruses may induce similar clinical pictures confirmation. Diagnosis is based on the detection of virus-specific RNA using nucleic acid amplification techniques from a respiratory sample such as a nasopharyngeal swab. This technique has been a breakthrough in the diagnosis as it could decrease unnecessary use of empirical antibiotic therapy. Other diagnostic methods are viral culture, usually less available and with longer turnaround time results, and direct viral detection in respiratory secretions by immunofluorescence or enzyme immunoassay, which shows lower sensitivity and specificity than PCR. Currently, there is no specific treatment against parainfluenza virus infections. Management of the infected patient is based on supportive therapy according to the clinical condition.

The main limitation of our case report is the unconfirmed etiological presence of parainfluenza virus in pericardial effusion. Detection of parainfluenza 3-specific RNA from pericardial fluid or blood would

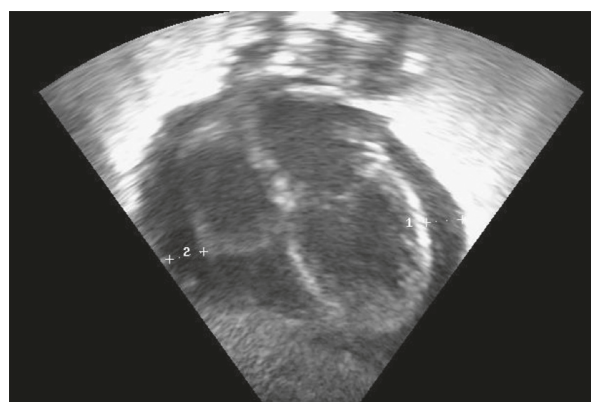

FIgURE 2: Echocardiography showing pericardial effusion. Dimensions: $1=0.43 \mathrm{~cm} ; 2=0.41 \mathrm{~cm}$.

offer direct evidence that PIV3 caused the effusion. Pericardial fluid was not obtained due to the invasiveness of the technique in the context of clinical and hemodynamic stability of our patient and spontaneous resolution in 5 days.

In conclusion, parainfluenza 3 infection should be considered during the diagnostic evaluation of neonatal pericarditis. This may prevent possible severe complications and reduce unnecessary use of antibiotics. High index of suspicion is required for rapid diagnosis and appropriate management.

\section{Abbreviations \\ BPD: Bronchopulmonary dysplasia \\ $\mathrm{FIO}_{2}$ : Fraction of inspired oxygen \\ LVO: Left ventricular output \\ NICU: Neonatal intensive care unit \\ PCR: Polymerase chain reaction \\ MAP: Mean airway pressure \\ RVO: Right ventricular output.}

\section{Ethical Approval}

Compliance with ethical standards.

\section{Consent}

Informed consent was obtained from the patient's parents.

\section{Conflicts of Interest}

The authors declare that there are no conflicts of interest regarding the publication of this case report.

\section{Authors' Contributions}

All authors have participated and worked actively: Drs. Cristina Aranda Cazón, Zarife Daoud Pérez, and José Tomás Ramos Amador have contributed especially from the infectious diseases point of view; Drs. Cristina Aranda Cazón, Luis Arruza Gómez, Gloria Herranz Carrillo, and José Antonio Martínez-Orgado from the neonatology approach; and Dr. Cristina González Menchén contributed mainly as a pediatric cardiologist. 


\section{References}

[1] J. A. Frank, R. W. Warren, J. A. Tucker, J. Zeller, and C. M. Wilfert, "Disseminated parainfluenza infection in a child with severe combined immunodeficiency," American Journal of Diseases of Children, vol. 137, no. 12, pp. 1172-1174, 1983.

[2] A. Ozkaya Parlakay, I. I. Cetin, H. Tezer, B. Gulhan, and T. Revide Sayli, "Parainfluenza virus 4 presenting with pericardial effusion in an immunocompetent child," Journal of Infection in Developing Countries, vol. 8, no. 8, pp. 1079-1080, 2014.

[3] N. Ohara, M. Kaneko, H. Kuwano et al., "Fulminant type 1 diabetes mellitus and fulminant viral myocarditis. A case report and literature review," International Heart Journal, vol. 56, no. 2, pp. 239-244, 2015.

[4] D. A. Rodríguez-Serrano, M. Nieto-Cabrera, J. Conesa, and E. Culebras-López, "Neumonía como resultado de la infección con parainfluenza tipo virus 4 y púrpura trombocitopénica trombótica," Medicina Intensiva, vol. 36, no. 3, p. 235, 2012.

[5] P. M. Smit, S. M. Pronk, J. C. Kaandorp et al., "RT-PCR detection of respiratory pathogens in newborn children admitted to a neonatal medium care unit," Pediatric Research, vol. 73, no. 3, pp. 355-361, 2013.

[6] N. J. Bennett, C. M. Tabarani, N. M. Bartholoma et al., "Unrecognized viral respiratory tract infections in premature infants during their birth hospitalization: a prospective surveillance study in two neonatal intensive care units," Journal of Pediatrics, vol. 161, no. 5, pp. 814-818, 2012. 


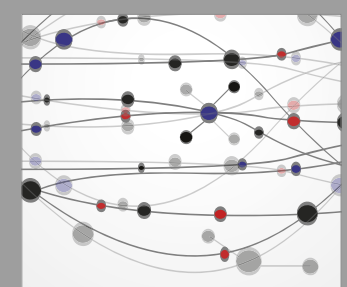

The Scientific World Journal
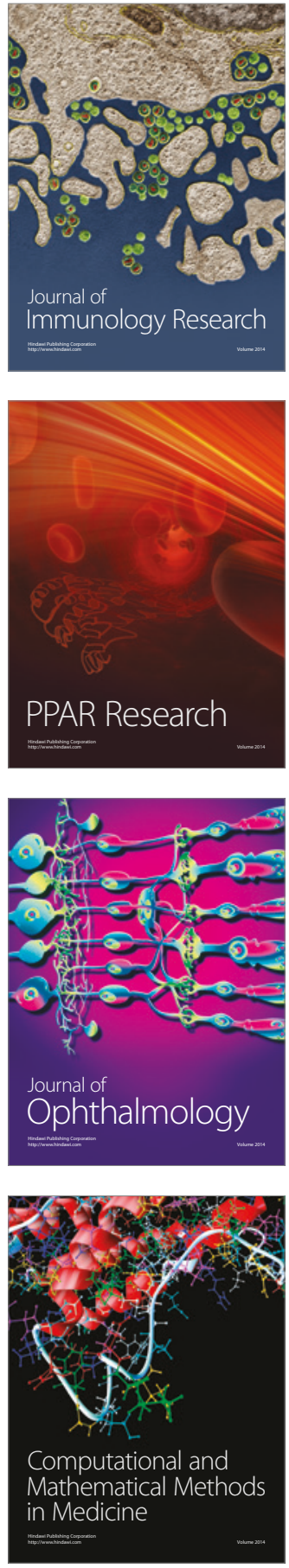

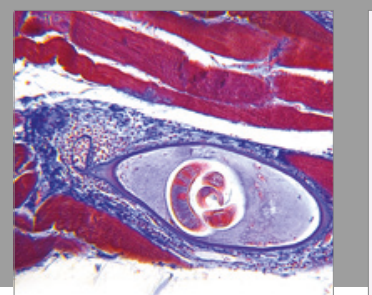

Gastroenterology Research and Practice
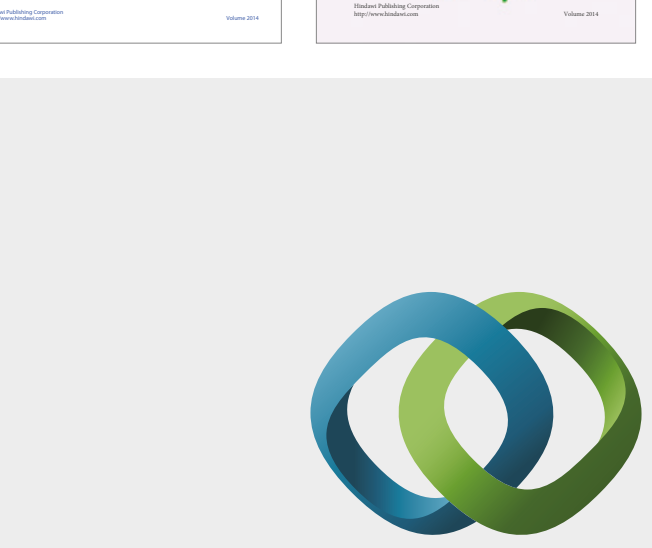

\section{Hindawi}

Submit your manuscripts at

https://www.hindawi.com
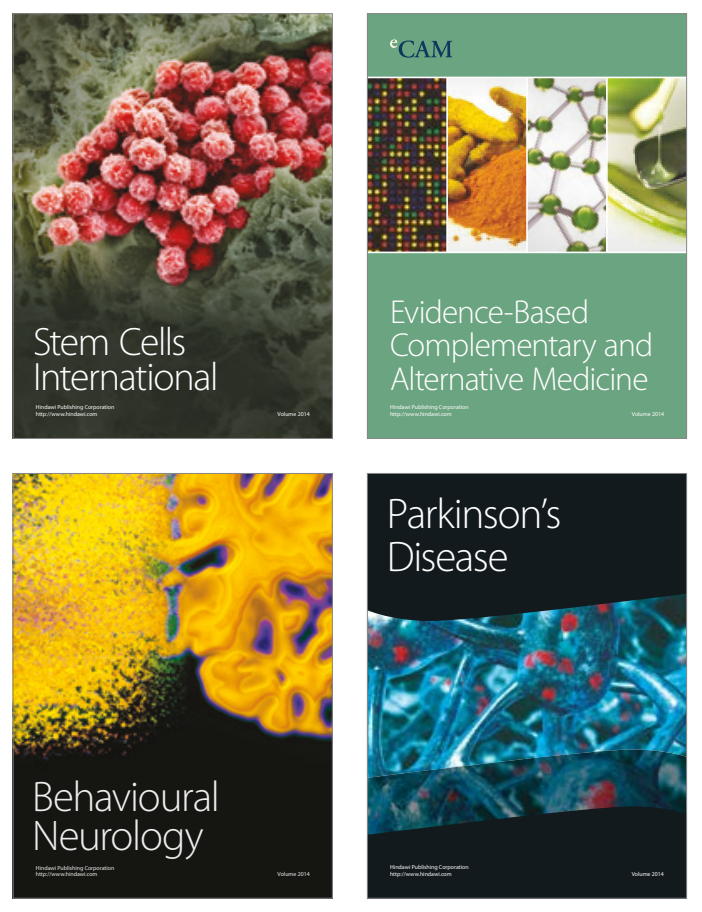
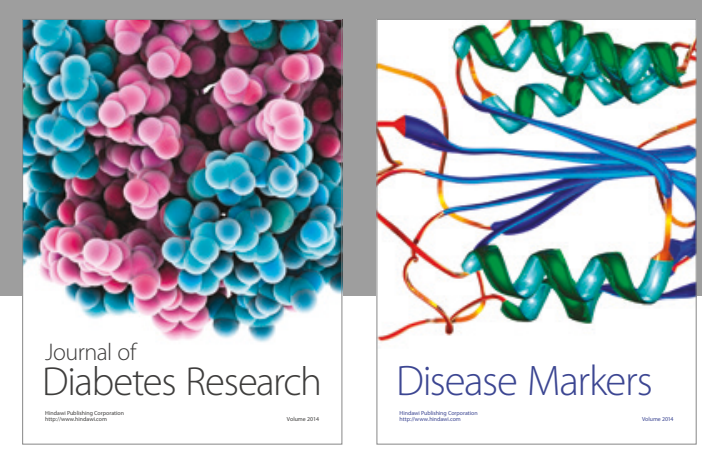

Disease Markers
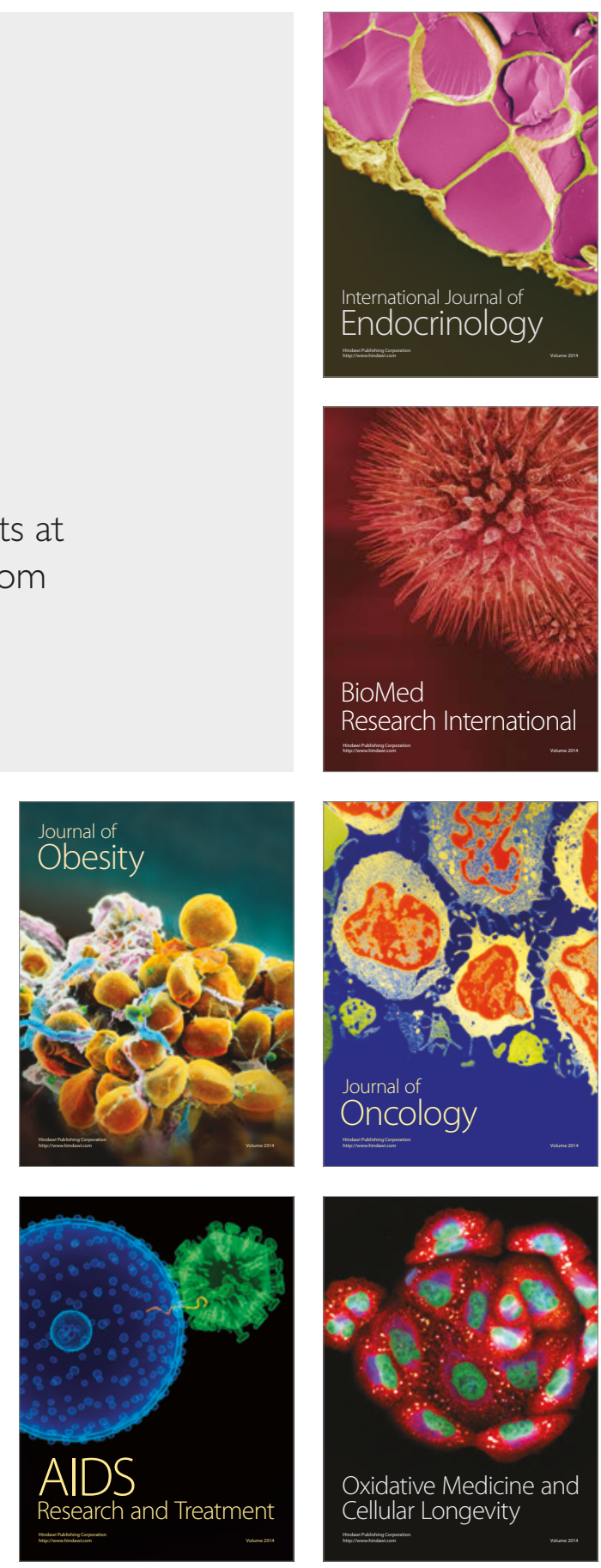